\title{
GERMINATION OF MAIZE SEEDS SOAKED IN MOLASSE AND VINASSE UNDER SALINITY STRESS CONDITIONS
}

\author{
A. A. A. Sweed ${ }^{(1)}$ and A. Awadalla ${ }^{(2)}$ \\ (1) Department of Soil and Natural Resources. ${ }^{(2)}$ Department of Agronomy. \\ Faculty of agriculture and Natural Resources, Aswan University, Aswan -Egypt
}

Received: Nov. 19, 2016

Accepted: Dec. 6 , 2016

\begin{abstract}
Salinity stress is one of the most severe environmental factors that reduce growth and development of plants. This study was carried out to evaluate the effects of salinity levels as $\mathrm{NaCl}$ salt and soaking with molasse and vinasse on germination parameters and length of both root and shoot of maize seedlings. Seeds of maize were germinated in glass Petri-dishes (10 cm in diameter). Ten seeds were put in each dish and moistened with 10 milliliters solutions of $\mathrm{NaCl}$ zero (control), 3.0, 6.0 and $9.0 \mathrm{dSm}^{-1}$ as salinity levels. The germination percentage, germination rate, germination index and length of both root and shoot were determined.

The obtained results showed that all growth parameters under study decreased with increasing the salinity level, except little positive impact on the length of root and shoot occurred with the seeds soaking in vinasse which the seeds tolerated of salinity. The results also showed that soaking the maize seeds in molasse reduced all germination parameters under study.
\end{abstract}

Key words: Maize, Salinity, Molasses, Vinasses and Growth parameters

\section{INTRODUCTION}

Salinity stress negatively impacts agricultural yields especially maize (corn) as a sensitive crop, throughout the world, affecting the production, whether for subsistence or economic gain. FAO (2000) showed that, at about $20 \%$ of the world's cultivated lands and approximately half of all irrigated lands and $2.1 \%$ of the dry agriculture lands are affected by salinity. Salinization is spreading more rapidly in the irrigated lands because of the inappropriate management of irrigation and drainage. Moreover, rain, cyclones and wind add $\mathrm{NaCl}$ to coastal agricultural lands (FAO, 2008).

Salinity due to the over-accumulation of soluble salts is usually of great concern and is the most damaging factor in arid and semi-arid regions. Salts-affected soils are widespread throughout the world, and their genesis may be natural or accelerated by irrigated agriculture, the intensive use of water resources combined with high evaporation rates and human activity (Lambers, 2003 and Arzani, 2008).

Salinity delays the onset, reduces the rate and increases the dispersion of germination events, resulting in reduction in plant growth and final crop yield (Ashraf and Foolad, 2005). Seeds are particularly vulnerable to stress encountered between sowing and seedling establishment while plant salt tolerance usually increases with plant ontogeny. Soil salinity may affect the germination of seeds either through creating high osmotic potential outside the seeds preventing water uptake or due to the direct toxic effects of $\mathrm{Na}^{+}$and $\mathrm{Cl}^{-}$ions on seed germination (Khajeh-Hosseini et al., 2003).

Different strategies for diminishing the adverse effects of salinity stress on plants are currently in practice. Concentrated vinasse is a by-product of sugar cane molasses fermentation. As an organic nutrient solution in the soil, vinasse has wide spectrum advantages. It improves almost all factors involved in the germination such as soil fertility, provides favoring conditions for nitrogen assimilation into the soil, protects the vinasse-nitrogen against leaching in winter and maintains it as a reserve nutrient to be slow release of during the growth 
period (Debruck and Lewicki, 1990). The application of vinasse at sowing was reported to result in an initial significant shortening $(P<0.05)$ of the primary rooting of ryegrass in three different studied soils (Murillo et al., 1993).

The present study aims to investigate effects of soaking maize seeds with molasses and vinasse on their seedling germination parameters under salinity stress conditions.

\section{MATERIALS AND METHODS Tested Plant Seeds}

Seeds of yellow maize (Zea mays L.) single cross hybrid (S.C 168) were selected as a test plant in this study. These seeds were obtained from Maize Research Department, Field Crop Research Institute Agriculture Research Center, Giza, Egypt. The seeds were hand sorted to eliminate the broken ones, selected randomly on the size uniformity basis, disinfected in $1 \% \mathrm{NaOCl}$ for 5 minutes, then, rinsed three times with distilled water and air-dried in the laboratory at the ambient temperature.

\section{Soaking Materials}

Two soaking materials were used in this study. The first one was molasses which was obtained from Kom-Ombo suger Factory at Kom-Ompo City, Aswan governorate and second material was vinasse which was taken from Egyptian Sugar Integration Industrial Company at AlHawamdia, Giza governorate, Egypt.

The chemical properties of both molasse and vinasse were analyzed as described in A.O.A.C. (1995) and they present in Table (1).

\section{Salinity Treatments}

Four of $\mathrm{NaCl}$ solutions have a 0.0 (control), 3.0, 6.0 and $9.0 \mathrm{dS} \mathrm{m}^{-1}(0,1755$, 3510 and $5265 \mathrm{mg} / \mathrm{l}$ ) were used as salinity treatments. Ten $\mathrm{ml}$ of each $\mathrm{NaCl}$ solution were transferred to petri-dishes $(10 \mathrm{~cm}$ in diameter). Also, seeds of the air-dried yellow maize were soaked in the used molasses and another similar number were soaked in the vinasse for $5 \mathrm{~min}$. The soaked seeds were air-dried. Ten seeds of yellow maize were put in each Petri-dish. The moisture content of each dish was adjusted at every day by adding distilled water by weight of each dish every day and calculate the loss of moisture to the control and saline solutions treatments in the dishes.

Table 1 Some chemical properties of molasse and vinasse.

\begin{tabular}{|l|c|c|}
\hline \multicolumn{1}{|c|}{ property } & Molasse & Vinasse \\
\hline $\mathrm{pH}$ & 4.95 & 4.14 \\
\hline $\mathrm{EC}\left(\mathrm{dS} \mathrm{m}^{-1}\right)$ & 75.20 & 66.70 \\
\hline Density $\left(\mathrm{g} / \mathrm{cm}^{3}\right)$ & 1.31 & 1.16 \\
\hline Organic matter (\%) & 25.60 & 13.22 \\
\hline Total nitrogen (\%) & 4.5 & 2.20 \\
\hline Total calcium (\%) & 1.35 & 1.70 \\
\hline Total potassium (\%) & 3.80 & 8.47 \\
\hline Total magnesium (\%) & 0.60 & 0.56 \\
\hline
\end{tabular}




\section{Experiment Design}

A laboratory experiment was done in the Faculty of Agriculture and natural resources, Aswan University, Egypt in February 2016. The experiment aimed to study the effects of soaking maize seeds in molasses and vinasse under different salinity levels as $\mathrm{NaCl}$ on the germination percentage (G.P), germination rate $(G . R)$, germination index (G.I) and both seedling root and shoot lengths. It was designed as a randomized complete block with three replications. A total of 36 Petri dishes with $10 \mathrm{~cm}$ diameter was used in this stady. The dishes of each salinity level were divided into three main groups. The first one was without using the soaking materials (control). The second and the third groups contain soaking treatments of molassrs and vinasses, respectively. Mean separation was done using the tukey test according to Steel and Torrie (1980). Germinated seeds were counted every 24 hours for 6 days until constant germination of the seeds in each dish. According to Sharma and Sharma (2010), seeds were considered to be germinated upon the emergence of radicles $(\geq 1 \mathrm{~mm})$. The lengths of root and shoot of the germinated seeds that are more than $1 \mathrm{~mm}$ were measured and recorded under all the studied treatments. At the end of the germination period (stability of germinated seeds in dishes) took bigger five seedlings in each Petri dishes which we measure their length of root and shoot as centimeters $(\mathrm{cm})$ and the following parameters were calculated as follow:

1- Germination percentage (GP) was calculated according to the equation: $\mathrm{GP}=\frac{n}{N} \times 100 \quad$ (Kandil et al., 2012)

Where $\mathrm{N}=$ Number of used seeds and $\mathrm{n}=$ Number of germinated seeds.

2- Germination rate (GR), which is important for the readiness state of early seedling growth was estimated as follows:

$G R=\left(X_{n}-\left(X_{n-1}\right) / Y_{n} \quad\right.$ (Kandil et al., 2012)
Where, $X_{n}=$ Number of germinated seeds at the $\mathrm{n}^{\text {th }}$ day and

$Y_{n}=$ Number of days from sowing until the $\mathrm{n}^{\text {th }}$ end time.

3- Germination index (GI) was calculated as described by the Association of Official Seed Analysis, AOSA (1983) according to the following formula:

$$
\mathrm{GI}=\left(\frac{G 1}{1}\right)+\left(\frac{G 2}{2}\right)+\left(\frac{G X}{X}\right) ; \quad(\mathrm{Li}, 2008)
$$

Where $\mathrm{Gl}=$ Germination index,

$\mathrm{G} 1, \mathrm{G} 2, \ldots \mathrm{Gx}=$ Germination in 1, 2, .....x day,

$1,2, \ldots x=$ the day in which germinated seeds were counted.

\section{RESULTS AND DISCUSSION}

Data in Table (2) show the adversely effect of salinity on germination parameters of maize seeds soaked in molasses and vinasse. The highest growth parameters were found in the control treatment $(0.00$ $\mathrm{NaCl})$. In this respect, Zadehbagheri (2014) obtained on similar results. These data may be discussed in detail as follows.

\section{a) Germination percentage}

The results in Table (2) and Figure (1) revealed that, the increase in the salinity level led to clear decline in the germination percentage (GP) with the same soaking treatment. The GP ranged from 100.00 to $86.67,86.67$ to 56.67 and 50.00 to $6.67 \%$ with the soaking of control, vinasse and molasses, respectively. Soaking the seeds in molasse leads to an increase of soluble salts in the medium of germination because it contains a high EC value $(75.2 \mathrm{dS} / \mathrm{m})$ compared to those of control and vinasse. In addition, the high absorption of $\mathrm{Na}$ and $\mathrm{Cl}$ by seeds ions during germination may be due to the cell toxicity that inhibits the rate of germination and thus decreases the GP. These results agree with those of Carpici et al. (2009), Sozharajan and Natarajan (2014) and Aliu et al. (2015). 


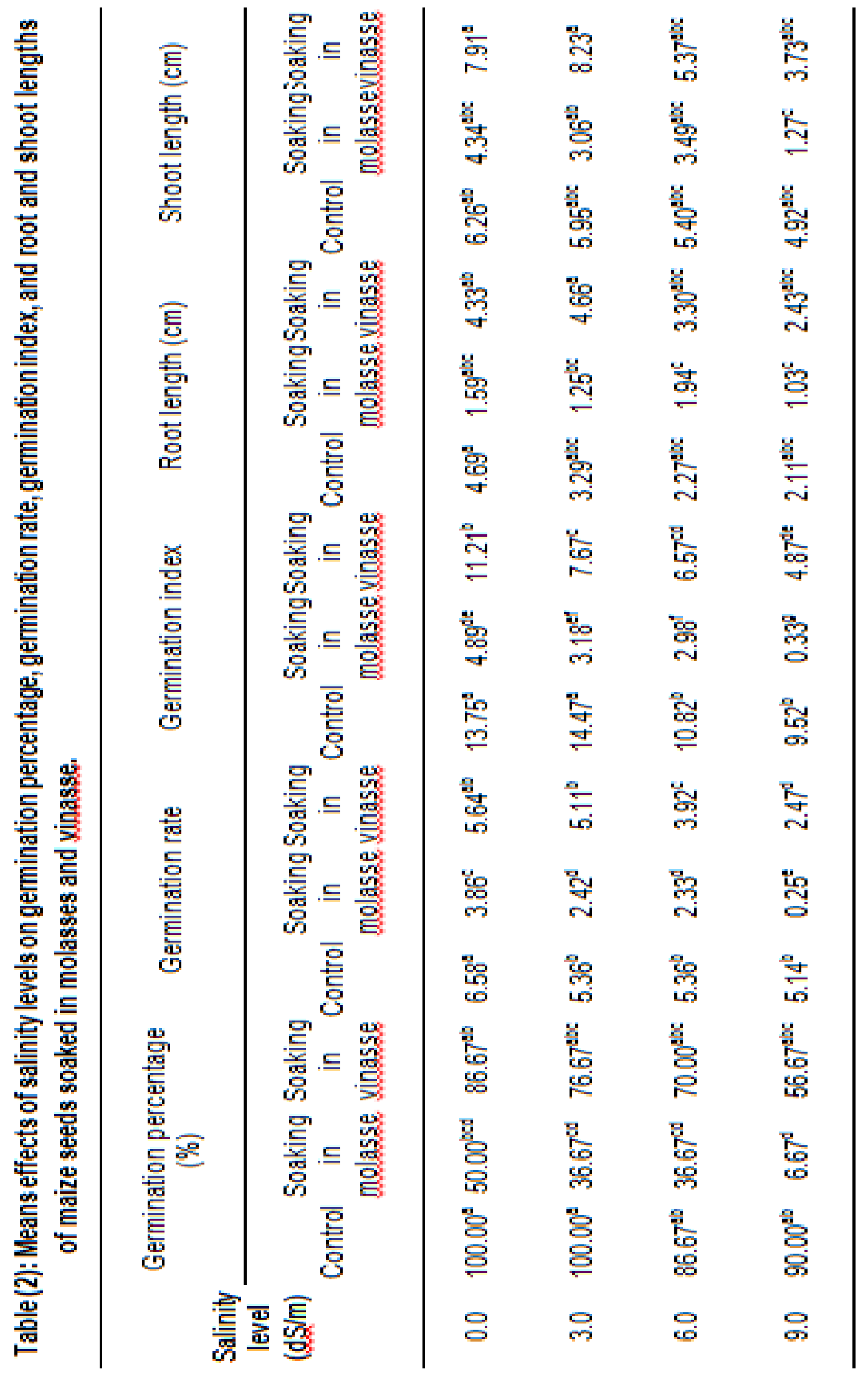




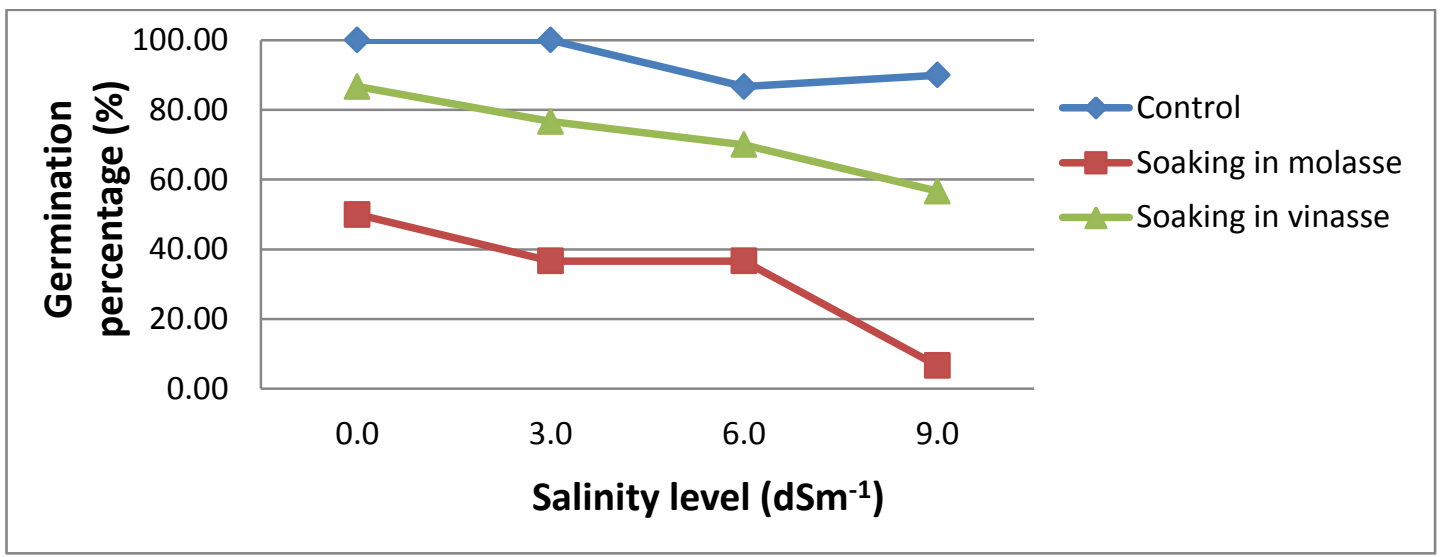

Figure (1). Effect of salinity level on the germination percentage of maize seeds soaked in molasses and vinasse.

\section{b) Germination rate}

Data in Table (2) and Fig. (2) show significant differences $(P<0.05)$ in the germination rate $(\mathrm{GR})$ of the maize seeds soaked by either molasse or vinasse due to the salinity effects. The GR decreased as the salinity level increased from 0.0 to 9.0 $\mathrm{dSm}^{-1}$. The same data show that, the GR ranged from 6.58 to $5.14,3.86$ to 0.25 and 5.64 to 2.47 with the soaking treatments of control, molasse and vinasse, respectively. Since the high salt concentration limits the water absorption by seeds, a decrease in the GR of these seeds occurs. Highest GR was recorded with the control followed with the soaking in vinasse and then the soaking in molasse. The low amounts of water absorbed by seeds prevent nutrient assimilation and retard the germination. These results agree with the findings of Akhtar and Hussain (2008), Kaydan and Yagmur (2008) and Tsegay and Gebreslassie (2014).

\section{c) Germination index}

The germination index (Gl) of maize seeds significantly decreased with increasing the salinity level (Table 2 and Fig. 3 ). So, the highest GI values were recorded for the EC treatment of $3.0 \mathrm{dS} / \mathrm{m}$. This means that, the relationship between salinity level and GI was negative. The obtained results reveal that, the $\mathrm{Gl}$ ranged from 14.47 to $9.52,4.89$ to 0.33 and 11.21 to 4.87 with the soaking treatments of control, molasse and vinasse, respectively. The seeds treated with molasse were more sensitive to the salinity level than those soaked in vinasse. The reduction in the $\mathrm{Gl}$ gets greater particularly at the salinity level $(\mathrm{NaCl})$ of 9.0 $\mathrm{dS} / \mathrm{m}$ compared to the control. An increase of $\mathrm{Gl}$ is indicative of decreased phytotoxicity and thus of a more mature germinated seeds (Khayatnez and Gholamin, 2011). These results are in a line with the findings of Tsegay and Gebreslassie (2014) and Aliu et al., (2015).

It has been reported by several authors that salinity stress affects seed germination either by decreasing the rate of water uptake (osmotic effect) and facilitating the intake of ions, which may change certain enzymatic or hormonal activities inside the seed (ion toxicity) (Huang and Redmann 1995).

\section{d) Root and shoot length}

The results in Table (2) and Fig. (4) indicated that, there are a reduction in root and shoot growth with increasing the salinity level. These decreases differed from 4.69 to $2.11 \mathrm{~cm}, 1.59$ to $1.03 \mathrm{~cm}$ and 4.33 to 2.43 $\mathrm{cm}$ in the root length and from 6.26 to 4.92 $\mathrm{cm}, 4.34$ to $1.27 \mathrm{~cm}$ and 7.91 to $3.73 \mathrm{~cm}$ in the shoot length with the soaking treatments of control, molasse and vinasse, respectively. The results also showed that 
soaking in vinasse caused an increase in the root and shoot growth, except at control level of salinity for root length and too at salinity level $9 \mathrm{dSm}^{-1}$ for shoot length. This was probably due to the soaking in vinasse led to increase concentration of nutrients in the growth medium because it contains a high percentage from nutrients compared to the control and molasses. Seedling growth was adversely affected under saline conditions. It is in an agreement with Cicek and Cakirlar (2002), who reported that the salinity reduced the shoot length, fresh and dry weight of maize seedlings.

Salinity affects the seedling growth of plants by slow or less suspending the cell division, enlargement and injuring hypocotyls (Tezara et al., 2003). Francois (1994) demonstrated that plants exhibit different sensitivities to salinity at different stages of growth. The root and shoot growth of salt sensitive plants reduces abruptly in saline environments. Giaveno et al. (2007) and Parvaiz and Satyawati (2008) obtained similar results.

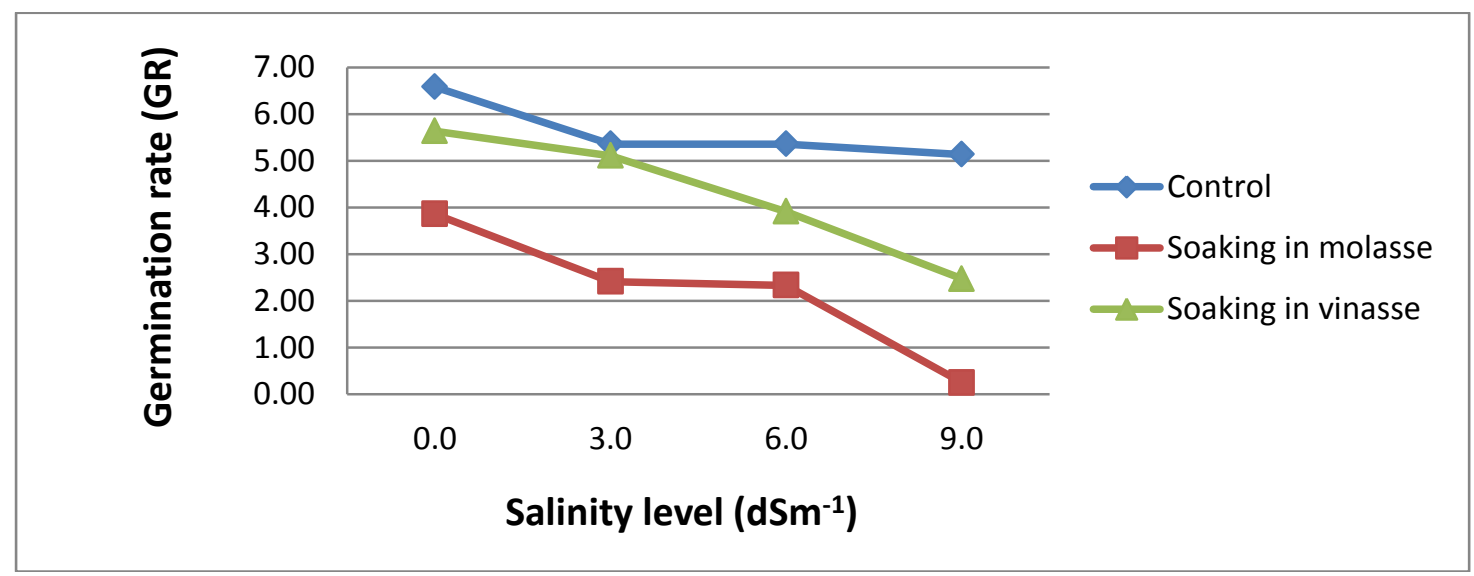

Figure (2). Effect of salinity level on the germination rate of maize seeds soaked in molasses and vinasse.

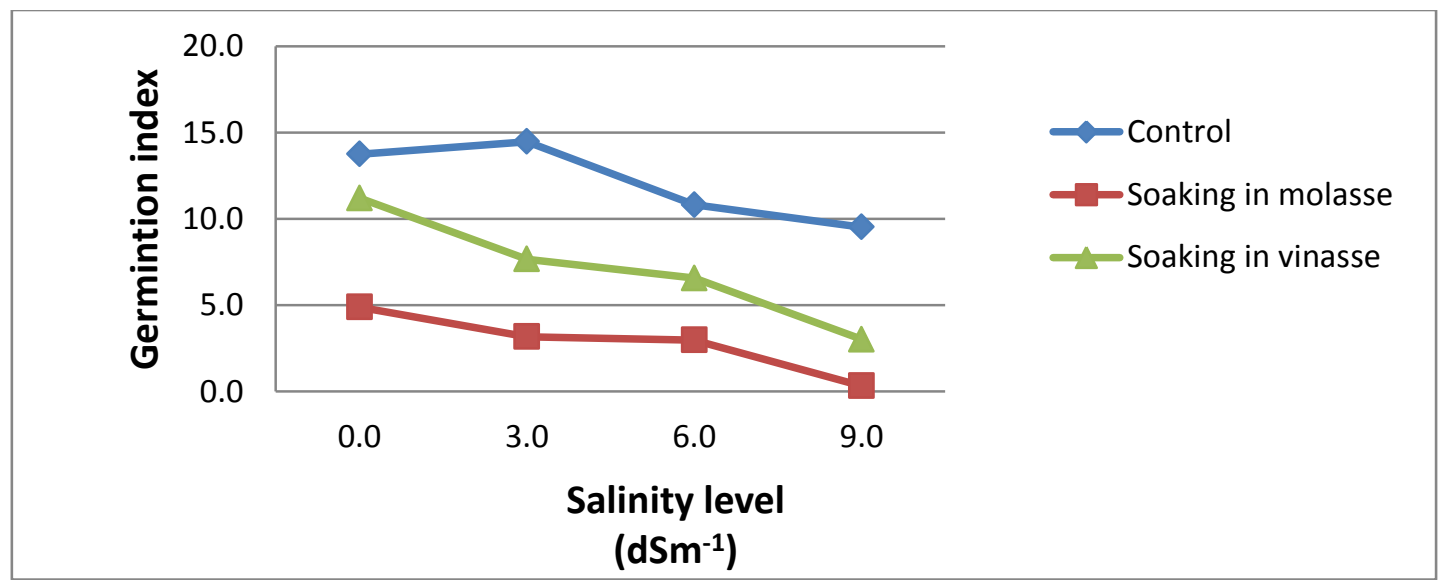

Figure (3). Effect of the salinity level on the germination index of maize seeds soaked in molasses and vinasse. 

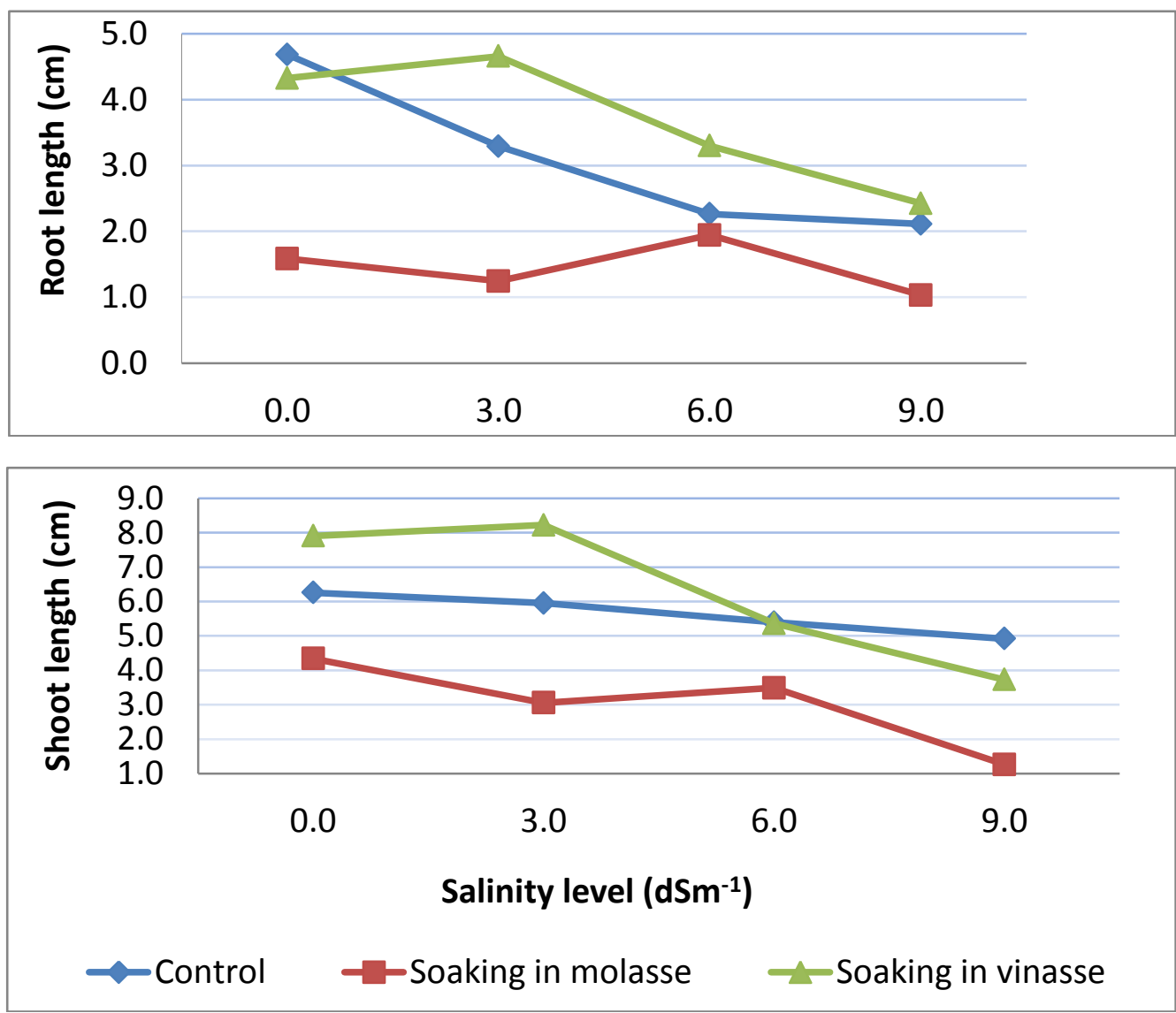

Figure (4). Effect of the salinity level on root and shoot lengths of maize seeds soaked in molasses and vinasse.

\section{CONCLUSION}

According to the results of this study, it may be concluded that, an increase in the salinity level $(\mathrm{NaCl})$ negatively effects on all germination parameters .i.e. the germination percentage, germination rate, germination index and length of both of root and shoot. Also, soaking treatments negatively affect on the germination parameters except the length of root and shoot that tolerate the salinity effect. The results also indicated that soaking maize seeds in molasses resulted in a decline in all germination parameters under study. This is possibly because the molasse increases the salinity level in the medium of germination which it contains a high amount of soluble salts.

Finally from the obtained results may be concluded that, if we used either of molasses or vinasse as a salt amendment must be application after seedling stage to prevent its decrease effect on germination percent and other growth parameters.

\section{REFERENCES}

Akhtar, P. and F. Hussain (2008). Salinity tolerance of three range grasses at germination and early growth stages. Pakistan Journal of Botany, 40: 2437 2441.

Aliu, S., I. Rusinovci, S. Fetahu, B. Gashi, E. Simeonovska and L. Rozman (2015). The effect of salt stress on the germination of maize (Zea mays L.) seeds and photosynthetic pigments.Acta Agriculturae Slovenica, 105: 85 - 94.

A.O. A. C. Association Official Analytical Chemists (1995). Official Methods of 
Analysis of the 16 ED . A .O . A . C International, Washington, D. C, U.S.A .

Arzani, A. (2008). Improving salinity tolerance in crop plants: a biotechnological view. Vitro Cell. Dev. Biology Plant 44: 373-383.

Ashraf, M. and M. R. Foolad (2005). Presowing seed treatment-a shotgun approach to improve germination growth and crop yield under saline and nonesaline conditions, Advanced of Agronomy, 88: 223-271.

Association of Official Seed Analysis (AOSA). (1983). Seed Vigour Testing Handbook. Contribution No. 32 to the handbook on Seed Testing, 18-19

Carpici, E.B., N. Celik and G. Bayram (2009). Effects of salt stress on germination of some maize (Zea mays L.) cultivars. African Journal of Biotechnology, 8(19): 4918-4922.

Cicek, N. and H. Cakirlar (2002). The effect of salinity on some physiological parameters in two maize cultivars. Bulgarian Journal of Plant Physiology, 28: 66-74.

Debruck, J. and W. Lewicki (1990). Sugar beet vinasse as organic nutrient solution. Ernahrungs dienst No. 29.

FAO. (2000). Global network on integrated soil management for sustainable use of salt-affected soils. Available in: http://www.fao.org/ag/AGL/agll/spush/intr o.htm (28.Jan.2015)

FAO. (2008). Land and Plant Nutrition Management Service. http://www.fao.org/ag/agl/agll/. Accessed on November/ 15/2012.

Francois, L.E. (1994). Growth, seed yield and oil content of canola grown under saline media. Agronomy of Journal. 26(86): $233-237$.

Giaveno, C.D., R.V. Ribeiro, G.M. Souza and R.F. De Oliveira (2007). Screening of tropical maize for salt stress tolerance. Crop Breeding and Applied Biotechnology 7: 304-313.

Huang, J. and R.E. Redmann (1995). Salt tolerance of Hordeum and Bassica species during germination and early seedling growth. Canadian Journal of Plant Science 75: 815-819.

Kandil, AA., AE. Sharief and SRH. Ahmed (2012). Germination and seedling growth of some chickpea cultivars (Cicer arietinum L.) under salinity stress. Journal Basic Appl. Science. 8: 561-571.

Kaydan, D. and M. Yagmur (2008). Germination, seedling growth and relative water content of shoot in different seed sizes of triticale under osmotic stress of water and $\mathrm{NaCl}$. African Journal of Biotechnology. 7: $2862-2868$.

Khajeh-hosseini, M., A.A. Powell and J. Binghaml (2003). The interaction between salinity stress and seed vigour during germination of soybean seeds, Seed Science and Technolology 31: 715-725.

Khayatnez, M. and R. Gholamin (2011). Effects of salt stress levels on five maize (zea mays L.) caltivars at germination stage. African Journal of Biotechnology. 10: $12909-12915$.

Lambers, H. (2003). Introduction, dry land salinity: a key environmental issue in Southern Australia. Plant Soil. 257, 5-7.

Li Y. (2008). Effect of salt stress on seed germination and seedling growth of three salinity plants. Pakistan Journal Bio. Science. 11: 1268-1272.

Murillo, J., F. Cabrera and R. Lopez (1993). Effect of beet vinasse on germination and seedling performance of ryegrass (Loliummultiflorum Lam cV Barwoltra. Journal of the Science of Food and Agriculture. 61: 155-160.

Parvaiz, A. and S. Satyawati (2008). Salt stress and phyto-biochemical responses of plants - a review. Plant Soil and Environment 54: 89-99.

Sharma, R.K. and S. Sharma (2010). Effect of storage and cold-stratification on seed physiological aspects of Bunium persicum: A threatened medicinal herb of Trans-Himalaya. International Journal of Botany. 6 (2): 151-156. 
Sozharajan, R. and S. Natarajan (2014). Germination and seedling growth of zea mays $L$. under different levels of sodium chloride stress. International Letters of Natural Sciences.12: 5 -15.

Steel, R.G.D. and J.H. Torrie (1980). Principle and Procedures of Statistics, a Biometrical Approach.McGrow-Hill Book Co. Second Edit, New York, USA.

Tezara, W., D. Martinez, E. Rengifo and A. Herrera (2003). Photosynthetic response of the tropical spiny shrub Lyciumnodosum (Solanaceae) to drought, soil salinity and saline spray. Annals of Botany. 92: 757-765.

Tsegay, B.A. and B. Gebreslassie (2014). The effect of salinity $(\mathrm{NaCl})$ on germination and early seedling growth of Lathyrussativus and Pisumsativum var. abyssinicum. African Journal of Plant Science. 8(5): $225-231$.

Zadehbagheri, M. (2014). Salicylic acid priming in corn (Zea mays L. var. Sc.704) Reinforces $\mathrm{NaCl}$ tolerance at germination and the seedling growth stage. International Journal of Biosciences. 4(5): 187-197. 
إنبات بذور الذرة المنقوعة في المولاس والفيناس تحت الاجهاد الملحي

(1) عاطف عبد العزيز علي سويد ، عبد المنعم عوض الله عمر(2)

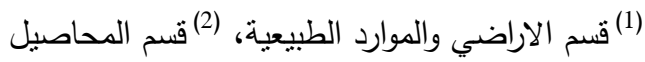

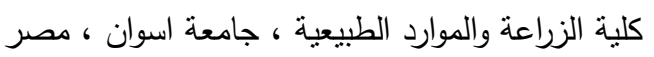

الملخص العربي

الملوحة هي احد أكثر العوامل البيئية الصعبة التي تحد من نمو وتطور النباتات .وقد أجريت هذه الدراسة لنقييم

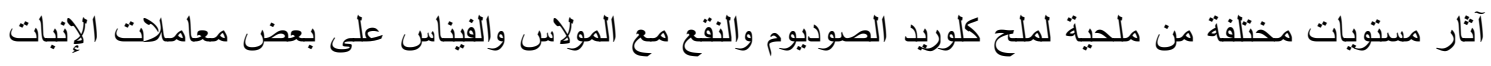

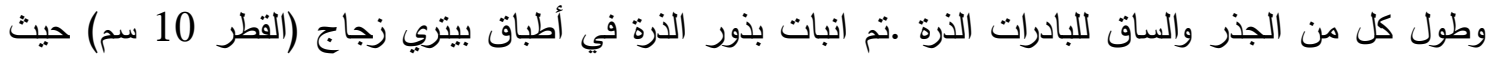

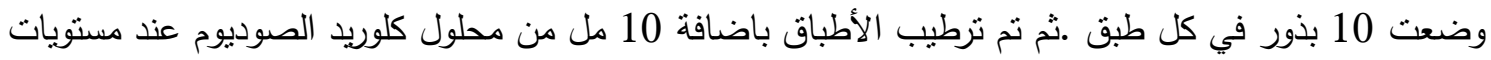
توصيل كهربي صفر (كنترول) ، 3 ، 6 و 9 ديسيمينز / م مكاب كوتم حساب النسبة المئوية للإنبات، معدل الإنبات، دليل الإنبات وطول كل من الجذر والساق لبادرات الذرة.

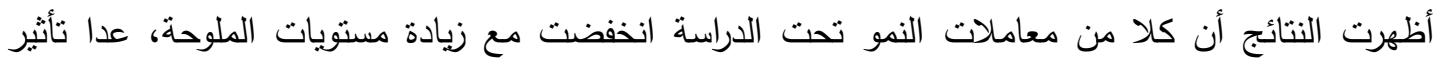

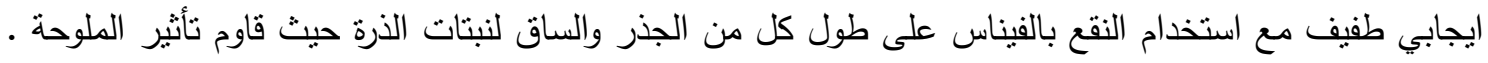
كما أثنارت النتائج إلى أن نقع بذور الذرة مع المولاس أدى إلى انخفاض في كل معاملات الإنبات تحت الدراسة. 